\title{
SNEB: Equity at the Core
}

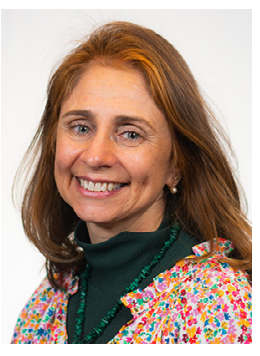

For my last Presidential Editorial, I will reflect on the past year. When my presidency started in a global pandemic, I did not think it would end in the pandemic. There is hope for a post-COVID-19 pandemic world. I am also hopeful for our Society's bright future.

My SNEB editorial, Forging the Future of Food and Nutrition Education, ${ }^{1}$ discussed the importance equity at the core of our field and SNEB.

I, along with the rest of the Board of Directors (BOD), dedicated ourselves to that goal. At our BOD meeting preceding the 2020 Annual Conference, we invited two experts, Dr Joanne Burke and Dr Karen Spiller to facilitate our equity journey. Our first activity was to place SNEB on a continuum for becoming an anti-racist, multicultural institution. $^{2}$ Our discussion on potential changes to become more anti-racist included hosting more conversations about racism that are open to our entire community.

Hence, on the first day of our 2020 virtual conference, we planned a Dismantling Racism Workshop. We had 600 people registered for the conference, and I thought we would be doing very well if 50 attended this workshop. We prepared the outcoming and incoming BOD members (about 15 people) to lead small group discussions. To my pleasant surprise, well over 200 people attended the workshop. The SNEB members are eager and ready to talk about racism. Our Executive Director, Rachel Daeger, scrambled to assign a leader to each breakout room. This was not ideal for those asked to lead without notice, nor for participants. I want our work on equity to be open, transparent, and smooth, so I vowed to do more and be better prepared. This is critically important work.

The BOD continued the journey in racial equity with 5 additional 2-hour sessions with Joanne and Karen throughout fall 2020. We dove into many topics, including the stages of racial identity development ${ }^{3}$ and decolonizing our diets. ${ }^{4}$

The SNEB has a strategic plan that leads our work. Our current plan has 3 big goals: (1) expand membership and membership benefits; (2) elevate and expand nutrition education research; and (3) provide leadership for our members and in the field of nutrition. We are embedding race, diversity, equity, and inclusion into this plan.

We are also initiating a Diversity, Equity, and Inclusion (DEI) committee being led by BOD Secretary Susan Stephenson-Martin. If you would like to join, please contact Rachel Daeger at rdaeger@sneb.org.

Our President-Elect and Conference Chair, Jasia Steinmetz, will have more about the conference in next month's editorial. For now, check our Annual Conference meeting agenda. ${ }^{5}$ A quick look at the 4 keynote sessions provides a glimpse into our focus on equity: (1) Trauma and Resilience: Food Justice; (2) The (R)evolution of Indigenous Food Systems of North America Accelerating Progress by Incorporating Equity into Obesity; (3) Accelerating Progress by Incorporating Equity into Obesity Prevention, Research, Policy, and Practice; and (4) What Does a "Sustainable Healthy Diet" Mean?: Introduction to the FAO/ WHO Guiding Principles on Sustainable Healthy Diets. Looking forward to seeing you there and continuing the conversation.

Pamela Koch, EdD, RD President, Society for Nutrition Education and Behavior

\section{REFERENCES}

1. Koch P. Forging the future of food and nutrition education. J Nutr Educ Behav. 2020;52:755-756.

2. Baily J, Hardiman R, Avazian A, Branding R. Continuum on Becoming an AntiRacist, Multicultural Institution. Crossroads Ministry; 2006

3. Parker CS, Willsea J. Summary of Stages of Racial Identity Development. Interaction Institute for Social Change; 2019.

4. Esquibel CR. Decolonize Your Diet: Notes Towards Decolonization. Food First; 2016

5. Society for Nutrition Education and Behavior. 2021 Annual Conference: Raising Reliance and Resilience. https://raybourn.force.com/SNEB/s/ltevent?id=a1Y1U000003DhqbUAC\#/ Overview. Accessed May 14, 2021. 